\title{
Prevalence and molecular characterization of Glucose-6-Phosphate dehydrogenase deficient variants among the Kurdish population of Northern Iraq
}

\author{
Nasir Al-Allawi*1 ${ }^{* 1}$, Adil A Eissa', Jaladet MS Jubrael2 ${ }^{2}$ Shakir AR Jamal ${ }^{1}$ and Hanan Hamamy ${ }^{3}$
}

\begin{abstract}
Background: Glucose-6-Phosphate dehydrogenase (G6PD) is a key enzyme of the pentose monophosphate pathway, and its deficiency is the most common inherited enzymopathy worldwide. G6PD deficiency is common among Iraqis, including those of the Kurdish ethnic group, however no study of significance has ever addressed the molecular basis of this disorder in this population. The aim of this study is to determine the prevalence of this enzymopathy and its molecular basis among Iraqi Kurds.

Methods: A total of 580 healthy male Kurdish Iraqis randomly selected from a main regional premarital screening center in Northern Iraq were screened for G6PD deficiency using methemoglobin reduction test. The results were confirmed by quantitative enzyme assay for the cases that showed G6PD deficiency. DNA analysis was performed on 115 G6PD deficient subjects, 50 from the premarital screening group and 65 unrelated Kurdish male patients with documented acute hemolytic episodes due to G6PD deficiency. Analysis was performed using polymerase chain reaction/restriction fragment length polymorphism for five deficient molecular variants, namely G6PD Mediterranean $(563 \mathrm{C} \rightarrow \mathrm{T})$, G6PD Chatham $(1003 \mathrm{G} \rightarrow \mathrm{A})$, G6PD A- (202 G $\rightarrow$ A), G6PD Aures $(143 \mathrm{~T} \rightarrow \mathrm{C})$ and G6PD Cosenza $(1376 \mathrm{G} \rightarrow \mathrm{C})$, as well as the silent $1311(\mathrm{C} \rightarrow \mathrm{T})$ mutation.

Results: Among 580 random Iraqi male Kurds, 63 (10.9\%) had documented G6PD deficiency. Molecular studies performed on a total of 115 G6PD deficient males revealed that 101 (87.8\%) had the G6PD Mediterranean variant and 10 (8.7\%) had the G6PD Chatham variant. No cases of G6PD A-, G6PD Aures or G6PD Cosenza were identified, leaving 4 cases (3.5\%) uncharacterized. Further molecular screening revealed that the silent mutation 1311 was present in 93/95 of the Mediterranean and 1/10 of the Chatham cases.

Conclusions: The current study revealed a high prevalence of G6PD deficiency among Iraqi Kurdish population of Northern Iraq with most cases being due to the G6PD Mediterranean and Chatham variants. These results are similar to those reported from neighboring Iran and Turkey and to lesser extent other Mediterranean countries.
\end{abstract}

\section{Background}

Glucose-6-Phosphate Dehydrogenase (G6PD) is a key enzyme in the pentose monophosphate pathway and provides the NADPH essential for a number of biosynthetic and detoxifying reactions. The gene encoding G6PD is located at Xq28, and its deficiency is the most common

\footnotetext{
*Correspondence: nallawi@yahoo.com

1 Department of Pathology, College of Medicine, University of Dohuk, Azadi Hospital road, 1014 AM Dohuk, Iraq

Full list of author information is available at the end of the article
}

enzymopathy in humans. As an X-linked recessive trait, it is predominantly a disease of males affecting an estimated 400 million people worldwide [1]. This deficiency is associated with a variable spectrum of clinical manifestations including the following: favism, neonatal jaundice, drug induced hemolysis, chronic non-spherocytic hemolytic anemia and infection induced hemolysis [2]. The latter variability is suggestive of biochemical heterogeneity. More than 400 G6PD biochemical variants have already been described [1]. More recently cloning and sequenc- 
ing of the G6PD gene allowed researchers to characterize more than 140 molecularly distinct variants [3].

G6PD deficiency is prevalent in many countries in the Eastern Mediterranean Region including Iraq [4-8]. Some studies have addressed the prevalence of G6PD deficiency in central and southern Iraq [8-10], but none are available from the northern region. The population of northern Iraq consists of a majority of ethnic Kurds unlike other parts of the country where Arabs predominate. Kurds constitute the fourth largest ethnic group in the Eastern Mediterranean after Arabs, Persians and Turks. They inhabit a region called Kurdistan covering adjacent parts of Iraq, Iran, Turkey and Syria. The origin of Kurds has been a subject of speculation. Based on cultural and linguistic evidence, some historians believe that Kurds are predominantly an Indo-European ethnic group who had migrated and settled in Iran, Iraq and Turkey more than 2000 years ago [11]. However the region has been inhabited by earlier populations since prehistoric times and has been ruled throughout its long history by several major powers including the Assyrians, Persians, Greeks, Romans, Arabs and Turks [12]. All these factors may have contributed to the genetic makeup of the present-day Kurds.

Genetic studies including those of inherited blood disorders are very scarce on Kurds, and such studies may help explain the origin and spread of these disorders and may also help shed some light on the history of this ethnic group. No study of significance has addressed the frequency of G6PD deficiency in the Kurdish Iraqi population, and none has defined the deficient molecular variants among any group of Iraqis, despite the fact that favism is a commonly encountered health problem throughout the country.

This study aims to: 1) determine the prevalence of G6PD deficiency in a random sample of healthy Iraqi Kurdish males attending a regional premarital screening center, and 2) define the molecular basis of G6PD deficiency among a sample of G6PD deficient males in the same region.

\section{Methods}

The study was conducted in the period between July and December 2009. The subjects enrolled were males attending the Central laboratory in Dohuk, northern Iraq for routine premarital health screening. This laboratory serves a population of around one million of mainly ethnic Kurds, and is the only facility in this province that is authorized to provide government mandated premarital investigations. The latter currently include investigation for blood groups, HBsAg, HIV and carrier screening for specific hemoglobinopathies. The center receives on average around $30-40$ couples per day. The study subjects were the male partners of the first 10 couples attending the center on every other working day throughout the study period.

A $6 \mathrm{ml}$ blood sample was collected in K2-EDTA tubes from each enrollee. The sample was used to screen for G6PD deficiency by methemoglobin reduction test [13]. All those identified as G6PD deficient and an equal number of age matched non-deficient individuals were further tested by quantitative enzyme assay according to the manufacturer instructions (Biolabo - France). Confirmed deficient individuals were recalled for molecular testing.

Additionally, 65 unrelated male patients who had documented hemolytic episodes associated with G6PD deficiency, were also recalled and had their G6PD deficient status reaffirmed by quantitative enzyme assay.

All G6PD deficient individuals had their DNA extracted by a phenol-chloroform based method [14]. The extracted DNA was screened sequentially for five G6PD deficient mutations namely G6PD Mediterranean (563 $\mathrm{C} \rightarrow \mathrm{T})$, G6PD Chatham (1003 G $\rightarrow \mathrm{A})$, G6PD Cosenza $(1376 \mathrm{G} \rightarrow$ C), G6PD Aures $(143 \mathrm{~T} \rightarrow \mathrm{C})$, G6PD A- $(202 \mathrm{G} \rightarrow \mathrm{A})$ and for silent $(1311 \mathrm{C} \rightarrow \mathrm{T})$ mutation using polymerase chain reaction/restriction fragment length polymorphism (PCR/RFLP) based method. These five deficient variants were selected for screening since they were the five most common variants reported in Iraq's surrounding countries [5,6,15-19]. The primers, amplified exons and restriction enzymes used for each of these reactions are outlined in table 1 . Further procedure details were performed as previously reported [20-23].

Informed consent was taken form all enrollees or their guardians and the study was approved by the appropriate ethical committee at the Dohuk college of Medicine, Iraq.

Statistical analysis utilized the Mann Whitney U test and Chi Squared test wherever appropriate. A p $<0.05$ was considered significant.

\section{Results}

Among 580 Kurdish male premarital screening subjects, 63 individuals (10.9\%) were found to be G6PD deficient by methemoglobin reduction test with all subsequently being confirmed as deficient by quantitative enzyme assay. Table 2 shows the G6PD enzyme levels in the deficient individuals as well as an equal number of age matched G6PD non-deficient males.

Among the 63 G6PD deficient males detected, 50 responded to a recall for molecular characterization. Additionally, 65 previously diagnosed males with G6PD deficiency associated documented hemolytic episodes also underwent quantitative enzyme assays (table 2) and molecular investigation. Molecular characterization of these 115 G6PD deficient individuals revealed that the G6PD Mediterranean $(563 \mathrm{C} \rightarrow \mathrm{T}$ ) was the most common and was detected in 101 of 115 individuals $(87.8 \%)$, followed by G6PD Chatham $(1003 \mathrm{G} \rightarrow \mathrm{A})$ that was detected 
Table 1: The primer sequences, exons amplified and the restriction enzymes used in the PCR/RFLP procedures to detect five G6PD deficient mutations and the silent one

\begin{tabular}{|c|c|c|c|}
\hline Variant & Primers & Exon amplified & Restriction Enzyme \\
\hline \multirow{2}{*}{$\begin{array}{l}\text { Mediterranean } \\
\text { ( } 563 \text { CTT) }\end{array}$} & 5'GGT GAG GCT CCT GAG TAC CA 3' & $V I$ & Mboll \\
\hline & 5'AGC TGT GAT CCT CAC TCC CC 3' & & \\
\hline \multirow{2}{*}{$\begin{array}{l}\text { Chatham } \\
\text { (1003 GTA) }\end{array}$} & 5'CAA GGA GCC САT TСТ СТС ССТ T 3' & $I X$ & BstXI \\
\hline & 5'TTC TCC ACA TAG AGG AGG ACG GCT GCC AAA GT3' & & \\
\hline \multirow{2}{*}{$\begin{array}{l}\text { A- } \\
(202 \text { GTA) }\end{array}$} & 5'CGT GTC CCC AGC CAC TTC TA 3' & $I I I-V$ & Nlalll \\
\hline & 5' CAC GCT CAT AGA GTG GTG GG 3' & & \\
\hline \multirow{2}{*}{$\begin{array}{l}\text { Cosenza } \\
\text { (1376 GTC) }\end{array}$} & 5'GCA GCC AGT GGG ATC AGC AAG 3' & $X I-X I I I$ & Bsu361 \\
\hline & 5' GGC AAG GAG GGT GGC CGT GG 3' & & \\
\hline \multirow{2}{*}{$\begin{array}{l}\text { Aures } \\
\text { (143 TTC) }\end{array}$} & 5' CAG CCA CTT CTA ACC ACA CAC Ct 3' & III & Mbol \\
\hline & 5' CCG AAG TTG GCC ATG CTG GG 3' & & \\
\hline \multirow{2}{*}{$\begin{array}{l}\text { Silent } \\
\text { (1311 CTT) }\end{array}$} & 5' TGT TCT TTC AAC CCC GAG GAG T 3' & Part $X-X I$ & $B C l l$ \\
\hline & 5' AAG ACG TCC AGG ATG AGG TGA TC 3' & & \\
\hline
\end{tabular}

in $10(8.7 \%)$. No cases with G6PD A-, Aures or Cosenza were identified. This left four cases (3.5\%) uncharacterized. There were no significant differences in the distribution of molecular G6PD variants among G6PD deficient individuals detected by screening and those with previously documented hemolytic episodes (table 3 ). On the other hand, the mean enzyme concentration of subjects with Mediterranean variant was significantly lower at $0.5798+0.357 \mathrm{IU} / \mathrm{g} \mathrm{Hb}$ than subjects with the Chatham variant at $0.846+0.3299 \mathrm{IU} / \mathrm{g} \mathrm{Hb}, \mathrm{P}=0.029$.

The silent mutation $(1311 \mathrm{C} \rightarrow \mathrm{T})$ was documented in 93/95 (97.8\%) of the Mediterranean deficient variants, in $1 / 10$ of the Chatham cases and in one of the three uncharacterized variants.

\section{Discussion}

G6PD deficiency has long been recognized as a common inherited hematological disorder in Iraqis including Kurds $[7,8]$. Kurds make up about $20 \%$ of the population of Iraq, and they live in Northern and Northeastern Iraq. The area covered by the current study in northern Iraq lies at the center of the Kurdish inhabited areas of the Eastern Mediterranean Region.

Earlier limited studies on G6PD deficiency among Iraqi Kurdish males living in Baghdad (at the center of the country) have reported frequencies of 7.6-8.8\% [7,9], which is slightly lower than the frequency of $10.9 \%$ as documented in this study. The latter rate is also higher than rates reported from the neighboring Kurdish population of western Iran [15], but is remarkably less than reports from Kurdish Jews, who have one of the highest rates worldwide of up to 58\% [24]. Previous studies from other parts of Iraq revealed variable results from Baghdad (6.1-12.4\%) at the center of country and 15.3\% from Basra at the extreme south [7-10]. As outlined in Table 4, polymorphic frequencies of G6PD deficiency were reported throughout the Eastern Mediterranean Region ranging from $2 \%$ in Lebanon to $39.8 \%$ in Eastern Saudi Arabia [4$10,15,25,26]$. The polymorphic frequency of G6PD deficiency in Iraq and in the Eastern Mediterranean Region may be linked to selective advantage against malaria in these previously highly endemic areas [1,27]. Northern Iraq was highly endemic in Malaria up to the fifties and sixties of the last century when control programs sponsored by the WHO managed to control the disease, but it remerged in the nineties particularly in the area covered by this study [28-30].

The predominance of the Mediterranean mutation (563 $\mathrm{C} \rightarrow \mathrm{T}$ ) as demonstrated in the current study, has been documented by many studies from the Eastern Mediterranean countries, where it constitutes 54 to $91 \%$ of G6PD variants identified (table 5) [5,6,15-19]. Our figures are comparable to those reported in Kurds from neighboring western Iran or from Kurdish Jews of $80-97 \%$ [15,24]. It is 
Table 2: Mean and standard deviation (SD) of G6PD enzyme concentrations (IU/g Hb) in the two G6PD deficient groups and healthy non-deficient males

\begin{tabular}{|c|c|c|c|}
\hline \multirow[t]{2}{*}{ Category } & \multirow[t]{2}{*}{ No } & \multicolumn{2}{|c|}{$\begin{array}{l}\text { G6PD Enzyme concentration } \\
\text { (IU/g Hb) }\end{array}$} \\
\hline & & Mean & SD \\
\hline Group A: G6PD deficient healthy individuals detected by premarital screening & 63 & 0.6670 & 0.445 \\
\hline Group B: G6PD deficient patients with history of hemolytic episode(s). & 65 & 0.6385 & 0.443 \\
\hline G6PD non-deficient healthy individuals & 63 & 12.206 & 0.827 \\
\hline
\end{tabular}

important to note that based on biochemical characterization, the Mediterranean variant has been presumably detected in $58.6 \%$ of 31 G6PD deficient males from an earlier study in Baghdad [9]. However, the small number of biochemically characterized deficient variants in the latter study and the fact that biochemical phenotypes are not absolutely related to particular molecular variants [31] would limit the feasibility of making reliable comparisons with the current study. The ethnic background of Baghdad's population is different from that of northern Iraq, thus the presumed lower frequency of the Mediterranean mutation maybe actual but would require molecular studies to be verified. The G6PD Mediterranean variant is also the predominant mutation among other Mediterranean countries like Italy and Greece as well as in the Indian subcontinent, but it is virtually non-existent in Central and South Africa and it shows a decreasing frequency as we move to the east from India (table 5) [3238]. As with other Mediterranean and Middle Eastern countries, the large majority of those with G6PD Mediterranean carry the silent $1311 \mathrm{C} \rightarrow \mathrm{T}$ mutation, and only 2 of the 95 cases tested in this study were non-carriers, the latter maybe due an intragenic recombinant event or population admixture $[15,39,40]$. Tishkoff and coworkers after studying some highly polymorphic microsatellites and RFLPs in and around the G6PD gene proposed that the Mediterranean mutation is of rather recent origin, originating somewhere in the Mediterranean basin within the past 1600 to 6640 years. Thereafter, it was spread to Middle East and North Africa by extensive trade routes and colonization by the Greeks in the first millennium BC. The pattern of distribution of the Mediterranean mutation (with the silent $1311 \mathrm{~T}$ mutation) makes it quite conceivable that it may have spread through the army of Alexander the Great who conquered the Middle East and North Africa and went as far east as India [41]. The Kurdistan region was a path which he used to pursue his conquests to Persia and beyond [12]. The mutation, thereafter, may have been selected for by malaria already highly endemic in these fertile agricultural lands, particularly around 500BC and thereafter. It is important to note that the Mediterranean mutation has also been reported predominantly without the silent mutation (i.e. with $1311 \mathrm{C}$ ) in the Indian subcontinent and southern Italy, which led many investigators to suggest two independent origins of the Mediterranean mutation $[34,39,42]$.

Table 3: The distribution of the G6PD deficient molecular variants in asymptomatic individuals detected by premarital screening and in patients with history of hemolytic episodes in the current study

Number of cases (\%)

\begin{tabular}{lccc}
\hline Category (no.) & Mediterranean & Chatham & Uncharacterized \\
\hline G6PD Deficient healthy individuals (50) & $45(90)$ & $3(6)$ & $2(4)$ \\
\hline G6PD Deficient patients (65) & $56(86.2)$ & $7(10.8)$ & $2(3.1)$ \\
\hline Total (115) & $101(87.8)$ & $10(8.7)$ & $4(3.5)$ \\
\hline
\end{tabular}


Table 4: Prevalence rates of G6PD deficiency in Iraq and some of the surrounding countries in Eastern Mediterranean Region

\begin{tabular}{|c|c|c|}
\hline Country & Prevalence (\%) & Ref \\
\hline Iraq: Central (Baghdad) & $6.1-12.3$ & {$[7-9]$} \\
\hline Iraq: Southern (Basra) & 15.3 & {$[10]$} \\
\hline Iraq: Northern (Kurds) & 10.9 & Current \\
\hline Iran: Western (Kurds) & 5.3 & {$[15]$} \\
\hline Jordan & 3.6 & [4] \\
\hline Kuwait & 5.5 & [4] \\
\hline Saudi Arabia & $1-39.8$ & {$[25,45,46]$} \\
\hline Syria & 3.0 & [4] \\
\hline Turkey & $0.5-20$ & {$[26]$} \\
\hline Bahrain & 18 & {$[47]$} \\
\hline Egypt & 5.9 & [48] \\
\hline Lebanon & 2.1 & [4] \\
\hline Oman & $2-29$ & [49] \\
\hline United Arab Emirates & 11 & {$[50]$} \\
\hline
\end{tabular}

The second most frequent variant detected by the current study is G6PD Chatham $(1003, \mathrm{G} \rightarrow \mathrm{A})$ seen in $8.7 \%$ of deficient individuals. G6PD Chatham, although first described in a patient of Asian Indian origin, is now recognized as one of the common variants worldwide [15]. Table 5 outlines the frequencies of the latter mutation in various Eastern Mediterranean countries and shows rather comparable figures among Iranian Kurds in western Iran [15]. However, figures for its frequency vary in other parts of the latter country reaching $27 \%$ in Northern Iran $[16,17]$. This variant may have been introduced to northern Iraq through gene flow from neighboring Iran.

G6PD Cosenza $(1376 \mathrm{G} \rightarrow \mathrm{C})$ was first described in Southern Italy [43] and has been reported in variable frequencies by some Iranian studies including the one on Kurds $[15,16]$. However, this variant was not detected in any deficient individual in the current study. G6PD Aures $(143 \mathrm{~T} \rightarrow \mathrm{C})$ was first described in Algeria [22]. Since then it has also been reported in variable frequencies in Jordan, Kuwait and western Saudi Arabia [18,19,44]. However it was not reported among Iranian Kurds or in neighboring Turkey $[15,26]$ as is the case in the current study.

The African A-variant (202 G $\rightarrow$ A) was not detected among our sample. This is in contrast to an earlier report from central Iraq where it was reported in 4.3\% of G6PD deficient subjects [9] and in some Arab Eastern Mediterranean countries where rates between 5.8-14.2\% were given (table 5 ). However, and similar to the current study, absence of the variant has also been described in reports on Iranian Kurds and Northern Iranians $[15,16]$. Absence of the variant in these areas is most likely related to the fact that the Kurdish inhabited areas of Iraq and neighbouring Iran were, unlike Arabia, a much less likely destination of African gene flow prior to or during the reign of the prosperous Islamic empire. 
Table 5: The distribution of five G6PD deficient variants (given as percentages) in different populations

\begin{tabular}{|c|c|c|c|c|c|c|c|}
\hline \multirow[t]{2}{*}{ Population } & \multirow[t]{2}{*}{ No. } & \multicolumn{5}{|c|}{ Deficient G6PD Variants (\%) } & \multirow[t]{2}{*}{ Ref } \\
\hline & & Mediterranean & Chatham & A- & Aures & Cosenza & \\
\hline Iraq: Northern (Kurds) & 115 & 87.8 & 8.7 & - & - & - & Current \\
\hline Iran: Western (Kurds) & 68 & 91.2 & 7.3 & - & - & 1.5 & {$[15]$} \\
\hline Iran: Northern (Mazandran) & 74 & 66.2 & 27 & - & - & 6.75 & {$[16]$} \\
\hline Iran: Southern (Fars) & 74 & 83.8 & 13.5 & 1.35 & - & - & [17] \\
\hline Jordan & 28 & 53.6 & 3.6 & 14.2 & 3.6 & - & [18] \\
\hline Kuwait & 89 & 74.2 & 10.1 & 12.4 & 3.0 & - & [19] \\
\hline Saudi Arabia: Eastern Province & 114 & 84 & - & 5.8 & - & - & {$[6]$} \\
\hline Turkey & 50 & 80 & 4 & 2 & - & - & {$[5]$} \\
\hline Italy & 162 & 69 & - & 3.7 & - & 1.2 & [32] \\
\hline India & 167 & 60.4 & 1.2 & - & - & - & [34] \\
\hline Malaysia: Malays & 86 & 26.7 & 2.3 & - & & - & [35] \\
\hline Algeria & 100 & 23 & 1 & 46 & 7 & 1 & {$[22]$} \\
\hline Nigeria & 89 & - & - & 100 & - & - & {$[36]$} \\
\hline
\end{tabular}

\section{Conclusion}

This study has documented that the frequency of G6PD deficiency among the predominantly Kurdish population in Northern Iraq is $10.9 \%$, which is higher than that reported from the neighboring Iranian Kurdish population. The study which is the first molecular study on G6PD deficient variants from Iraq documented that G6PD Mediterranean and Chatham constitute the large majority of the deficient variants which is similar to findings reported in surrounding populations. Further studies including larger number of patients, more diverse ethnic backgrounds and including screening for other deficient variants and DNA sequencing are needed to give a more comprehensive view of G6PD variants in Iraqis.

\section{Competing interests}

The authors declare that they have no competing interests.

\section{Authors' contributions}

$\mathrm{NA}$, contributed the concept and design, part of the molecular studies, data analysis and drafting of the manuscript; $A A E$, contributed to the collection of data, larger part of the molecular work and analysis of data; JMSJ, contributed to the concept and design and part of the molecular work; SARJ, contributed to collection of data, performing hematological, enzyme assays and data analysis; $\mathrm{HH}$, contributed to the analysis and interpretation of results, drafting and revision of the manuscript. All authors revised and approved the final submitted version of the manuscript.

\section{Acknowledgements}

The research was supported by a grant from University of Dohuk, Dohuk, Iraq.

Author Details

'Department of Pathology, College of Medicine, University of Dohuk, Azadi Hospital road, 1014 AM Dohuk, Iraq, ${ }^{2}$ Scientific Research Center, University of Dohuk, Dohuk, Iraq and 3Department of Genetic Medicine and Development, Geneva University Hospital, Geneva, Switzerland

Received: 27 March 2010 Accepted: 5 July 2010

Published: 5 July 2010

\section{References}

1. Beutler E: G6PD deficiency. Blood 1994, 84:3613-3636.

2. Beutler E: Glucose-6-Phosphate Dehydrogenase deficiency: a historical perspective. Blood 2008, 111:18-24.

3. Beutler E, Vulliamy TJ: Hematologically important mutations: glucose-6phosphate dehydrogenase. Blood Cells Mol Dis 2002, 28:93-103. 
4. Usanga EA, Ameen R: Glucose-6-Phosphate Dehydrogenase deficiency in Kuwait, Syria, Egypt, Iran, Jordan and Lebanon. Hum Hered 2000, 50:158-161.

5. Oner R, Gümrük F, Acar C, Oner C, Gürgey A, Altay C: Molecular characterization of glucose-6-phosphate dehydrogenase deficiency in Turkey. Haematologica 2000, 85:320-321.

6. Al-Ali AK, Al-Mustafa ZH, Al-Madan M, Qaw F, Al-Ateeq S: Molecular characterization of glucose-6-phosphate dehydrogenase deficiency in the eastern Province of Saudi Arabia. Clin Chem Lab Med 2002, 40:814-816

7. Amin-Zaki L, Taj Al-Din S, Kubba K: Glucose-6-phosphate dehydrogenase deficiency among ethnic groups in Iraq. Bull World Health Organ 1972, 47:1-5.

8. Hamamy H, Saeed T: Glucose-6-phosphate dehydrogenase deficiency in Iraq. Hum Genet 1981, 58:434-435.

9. Hilmi FA, Al-Allawi NA, Rassam M, Al-Shamma G, Al-Hashimi A: Red cell glucose-6-phosphate dehydrogenase phenotypes in Iraq. East Mediterr Health J 2002, 8:1-6

10. Hassan MK, Taha JY, Al-Naama LM, Widad NM, Jasim SN: Frequency of haemoglobinopathies and glucose-6-phosphate dehydrogenase deficiency in Basra. East Mediterr Health J 2003, 9:1-7.

11. Arshi Z, Zabihi K: Kurdistan. Ostersund: Oriental art publications; 1990.

12. Izady MR: The Kurds: a concise handbook. Washington: Taylor and Francis International Publishers; 1992.

13. Brewer GJ, Tarlove AR, Alving AS: The methemoglobin reduction test from primaquine-type sensitivity to erythrocytes. JAMA 1962, 180:386-388.

14. Bass F, Bikker H, Ommen GJ, Vijlder J: Unusual scarcity of restriction site polymorphisms in human thyroglobin gene: A linkage study suggesting autosomal dominance of defective thyroglobin allele. Hum Genet 1984, 67:301-305.

15. Rahimi Z, Vaisi-Raygani A, Nagel RL, Muniz A: Molecular characterization of glucose-6-phosphate dehydrogenase deficiency in the Kurdish population of Western Iran. Blood Cells Mol Dis 2006, 37:31-37.

16. Mesbah-Namin SA, Sanati MH, Mowjoodi A, Mason PJ, Vulliamy TJ, NooriDaloii M: Three major glucose-6-phosphate dehydrogenase-deficient polymorphic variants identified in Mazandaran state of Iran. $\mathrm{Br} J$ Haematol 2002, 117:763-764

17. Karimi M, Martinez di Montemuros F, Danielli MG, Farjadian S, Afrasiabi A, Fiorelli G, Cappellini MD: Molecular characterization of glucose-6phosphate dehydrogenase deficiency in the Fars province of Iran. Hematologica 2003, 88:346-347.

18. Karadsheh NS, Moses L, Ismail SI, Devaney JM, Hoffman E: Molecular heterogeneity of glucose-6-phosphate dehydrogenase deficiency in Jordan. Hematologica 2005, 90:1693-1694

19. AlFadhli S, Kaaba S, Elshafey A, Salim M, AlAwadi A, Bastaki L: Molecular characterization of glucose-6-phosphate dehydrogenase gene defect in the Kuwaiti population. Arch Path Lab Med 2005, 129:1 144-1147.

20. Pietrapertosa A, Palma A, Campanale D, Delios G, Vitucci A, Tannoia N Genotype and phenotype correlation in Glucose-6-Phospahate dehydrogenase deficiency. Haematologica 2001, 86:30-35.

21. Noori-Daloii MR, Hejazi SH, Yousefi A, Mohammad Ganji S, Soltani S, Javadi $\mathrm{KR}$, Sanati MH: Identification of mutations in G6PD gene in patients in Hormozgan province of Iran. J Sci I R Iran 2006, 17:313-316.

22. Nafa K, Reghis A, Osmani N, Baghli L, Ait-Abbes H, Benabadji M, Kaplan J-C, Vulliamy T, Luzzatto L: At least five polymorphic variants account for the prevalence of glucose 6-phosphate deficiency in Algeria. Hum Genet 1994, 94:513-517.

23. Cittadella R, Civitelli D, Manna I, Azzia N, Di Cataldo A, Schiliro G, Brancati C: Genetic heterogeneity of glucose 6-phosphate dehydrogenase deficiency in south-east Sicily. Ann Hum Genet 1997, 61:229-234.

24. Oppenheim A, Jury CL, Rund D, Vulliamy TJ, Luzzatto L: G6PD Mediterranean accounts for the high prevalence of G6PD deficiency in Kurdish Jews. Hum Genet 1993, 91:293-294.

25. Warsy AS, El-Hazmi MAF: G6PD deficiency, distribution and variants in Saudi Arabia: an overview. Ann Saudi Med 2001, 21:174-177.

26. Altay C, Gümrük F: Red Cell glucose-6-phosphate dehydrogenase deficiency in Turkey. TurkJ. Hematol 2008, 25:1-7.

27. Durand PM, Coetzar TL: Hereditary Red cell disorders and malaria resistance. Haematologica 2008, 93:961-963.

28. Niazi AD: Malaria situation in Zakho Qadha - Mousel liwa. Bull End em Dis (Baghdad) 1968, 10:185-194.
29. Abul-Hab J: Malaria vector survey in north Iraq. I. Provinces of Naynawah and Dhook. Bull Endem Dis (Baghdad) 1969, 11:117-133.

30. Saeed SY, Al-Saeed AT: Descriptive epidemiology of malaria in Dohuk governorate from 1990-1997. Univ DohukJ 1999, 2:347-354.

31. Cappellini MD, Martinez di Montemuros F, Bellis G, Debernardi S, Dotti $C$ Fiorelli G: Multiple G6PD Mutations are associated with a clinical and biochemical phenotype similar to that of G6PD Mediterranean. Blood 1996, 87:3953-3958

32. Martinez di Montemuros FM, Dotti C, Tavazzi D, Fiorelli G, Cappellini MD: Molecular heterogeneity of glucose-6-phosphate dehydrogenase (G6PD) Variants in Italy. Hematologica 1997, 82:440-445

33. Menounos P, Zevas C, Garinis G, Doukas C, Kolokithopoulos D, Tegos C, Patrinos GP: Molecular heterogeneity of the glucose-6-phosphate dehydrogenase deficiency in the Hellenic population. Hum Hered 2000, 50:237-241.

34. Sukumar S, Mukherjee MB, Colah RB, Mohanty D: Molecular basis of G6PD deficiency in India. Blood cell Mol Dis 2004, 33:141-145.

35. Ainoon O, Yu YH, Amir Muhriz AL, Boo NY, Cheong SK, Hamidah NH: Glucose-6-phosphate dehydrogenase (G6PD) variants in Malaysian Malays. Hum Mutat 2003, 21:101.

36. Ademowo OG, Falusi AG: Molecular epidemiology and acctivity of erythrocyte G6PD variants in a homogeneous Nigerian population. East African Med J 2002, 79:42-44.

37. Wang J, Luo E, Hirai M, Arai M, Abdul Manan EAS, Isa ZM, Hidayah NI, Matsuoka $\mathrm{H}$ : Nine different glucose-6-phosphate dehydrogenase (G6PD) variants in a Malaysian population with Malay, Chinese, Indian and Orang Asli (Aboriginal Malaysian) backgrounds. Acta Medica Okayama 2008, 62:327-332.

38. Matsuoka H, Arai M, Yoshida S, Tantular IS, Pusarawati S, Kerong H, Kawamoto F: Five different glucose-6-phosphate dehydrogenase (G6PD) variants found among 11 G6PD-deficient persons in Flores Island, Indonesia. J Hum Genet 2003, 48:542-544

39. Beutler E, Kuhl W: The NT 1311 polymorphism of G6PD: G6PD Mediterranean mutation may have originated independently in Europe and Asia. Am J Hum Genet 1990, 47:1008-1012.

40. Kurdi-Haidar B, Mason PJ, Berrebi A, Ankra-Badu G, Al-Ali A, Oppenhheim $A$, Luzzatto $L$ : Origin and spread of glucose-6-phosphate dehydrogenase variant (G6PD-Mediterranean) in the Middle East. Am J Hum Genet 1990, 47:1013-1019.

41. Tishkoff SA, Vasrkonyi R, Cahinhinan N, Abbes S, Argyropoulos G, DestroBisol G, Drousiotou A, Dangerfield B, Lefranc G, Loiselet J, Piro A, Stoneking M, Tagarelli A, Tagarelli G, Touma EH, Williams SM, Clark AG: Haplotype diversity and Linkage disequilibrium at human G6PD: Recent origin of alleles that confer malarial resistance. Science 2001, 293:455-462.

42. Moiz B, Nasir A, Moatter T, Naqvi ZA, Khurshid M: Population study of $1311 \mathrm{C} / \mathrm{T}$ polymorphism of glucose 6 phosphate dehydrogenase gene in Pakistan - an analysis of 715 X-chromosomes. BMC Genetics 2009, 10:41

43. Calabro V, Mason PJ, Filosa S, Civitelli D, Cittadella R, Tagarelli A, Martini G, Brancati C, Luzzatto L: Genetic heterogeneity of glucose-6-phosphate dehydrogenase deficiency revealed by single stranded conformation and sequence analysis. Am. J. Hum Genet 1993, 52:527-536.

44. Al Jaouni SK: Molecular clinical correlation of glucose 6-phosphate deficiency in western Saudi Arabia. Haematologica 2006, 91(S1):24-25

45. Nasserullah Z, Al Shammari A, Abbas MA, Abu-Khamseen Y, Qaderi M, A Jafer S, Al Wabe M: Regional experience with newborn screening for sickle cell disease, other hemoglobinopathies and G6PD deficiency. Ann Saudi Med 2003, 23:354-357.

46. Alabdulaali MK, Alayed KM, Alshaikh AF, Almashhadani SA: Prevalence of glucose-6-phosphate dehydrogenase deficinecy and sickle cell trait among blood donors in Riyadh. Asian J Transf Sci 2010, 4:31-33.

47. Al Arrayed S: Campaign to control genetic blood diseases in Bahrain. Community Genet 2005, 8:52-55.

48. Hussein L, Yamamah G, Saleh A: Glucose-6-phosphate dehydrogenase deficiency and sulfadimidin acetylation phenotypes in Egyptian oases. Biochem Genet 1992, 30:113-121.

49. Al-Riyami A, Ebrahim GJ: Genetic Blood Disorders Survey in the Sultanate of Oman. JTrop Pediatr 2003, 49(Suppl 1):i1-20.

50. Bayoumi RA, Nur-E-Kamal MS, Tadayyon M, Mohamed KK, Mahboob BH, Quereshi MM, Lekhani MS, Awaad MO, Vulliamy TJ, Luzzatto L: Molecula characterization of erythrocyte glucose-6-phosphate dehydrogenase 
deficiency in Al-Ain District, United Arab Emirates. Hum Hered 1996 46:136-141.

\section{Pre-publication history}

The pre-publication history for this paper can be accessed here: http://www.biomedcentral.com/1471-2326/10/6/prepub

doi: 10.1186/1471-2326-10-6

Cite this article as: Al-Allawi et al., Prevalence and molecular characterization of Glucose-6-Phosphate dehydrogenase deficient variants among the Kurdish population of Northern Iraq BMC Blood Disorders 2010, 10:6

Submit your next manuscript to BioMed Central and take full advantage of:

- Convenient online submission

- Thorough peer review

- No space constraints or color figure charges

- Immediate publication on acceptance

- Inclusion in PubMed, CAS, Scopus and Google Scholar

- Research which is freely available for redistribution

Submit your manuscript at www.biomedcentral.com/submit 